\title{
Alternative Process for Production of Sweet Potato Distilled Beverage
}

\section{Caroline Trevisan Weber ${ }^{1^{\star}}$}

https://orcid.org/0000-0001-9152-0949

Tiago Casagrande ${ }^{1}$

https://orcid.org/0000-0002-9586-8122

\section{Gabriela Candido 1}

https://orcid.org/0000-0002-3068-1455

Luciane Ferreira Trierweiler ${ }^{1}$

https://orcid.org/0000-0003-4497-7334

\section{Jorge Otávio Trierweiler ${ }^{1}$}

https://orcid.org/0000-0002-6328-945X

${ }^{1}$ Federal University of Rio Grande do Sul, Department of Chemical Engineering , Porto Alegre, Rio Grande do Sul, Brazil.

Received: 2019.03.26; Accepted: 2020.02.13.

*Correspondence: caroltw@enq.ufrgs.br; Tel.: +55-51-33083444

\section{HIGHLIGHTS}

- Sweet potato waste can be used for distilled beverages production.

- Alternative process to produce a beverage similar to shochu.

- Use of enzymes instead of koji, reducing production time from 14 to 1 day.

- Addition of pectinase in fermentation causes higher formation of methanol.

\begin{abstract}
Shochu is the most widely consumed spirit in Japan. In its manufacture is used koji, a solid fungus culture traditional of the Asian countries, but that makes the production process slow. Shochu can be produced from a variety of starchy sources, including sweet potato. About $7 \%$ of the world's sweet potato production is wasted due to imperfections that make it unsuitable for consumption. However, this material can be used in ethanol production. Considering the high productivity of sweet potato in Brazil, an opportunity to add value to this raw material is perceived. An alternative process for the production of sweet potato distillate similar to shochu was proposed. Koji was replaced by a mixture of alpha-amylase and glucoamylase. Process time was reduced from 14 to only 1 day. Composition analyses were performed by HPLC and GC. The experimental yield of alcoholic fermentation using pectinase enzyme reached $67.31-73.65 \%$, but methanol was above the limits of the legislation. Without the addition of pectinase, no methanol was formed. However, there was a decrease in yield (51.65-54.75\%), due to the incomplete disintegration of sweet potatoes. The distillate produced and the commercial shochu presented the same absorption bands in FTIR analysis, identifying the similarity between them.
\end{abstract}

Keywords: tuber crops; ethanol; alcoholic beverage; shochu; enzymatic process. 


\section{INTRODUCTION}

In Brazil, the majority of bioethanol is produced by fermentation of sugarcane. However, other raw materials such as the ones rich in cellulosic fibers and starch might be used as well [1]. The sweet potato crop, a human food with good nutritional content, has great importance in animal feed and industrial production of flour, starch, and alcohol. It occupies the sixth place among the most planted vegetables in Brazil, being cultivated in all the regions of the country, with emphasis on the South. Although in its cultivation little technology is used, the productivity of sweet potato has been increasing in the last years [2], reaching 60 tons per hectare [3].

About $53 \%$ of the sweet potato production is used in animal feed and $40 \%$ goes for human consumption. If there are cuts in the sweet potato, fungi, and bacteria will lodge in the food, making it unfit for consumption. The global amount of sweet potato waste in 2011 accounted for about $7 \%$ of the entire crop [4]. However, this imperfect material could be used for other purposes, such as ethanol production. This fact, together with the knowledge of the enzymatic hydrolysis process of starch in fermentable sugars, allows the transformation of this raw material into alcoholic beverages, making it possible to diversify the production and to use sweet potatoes unfit for commercialization, adding value to it.

The beverage industry is an important industrial sector, being responsible for $3 \%$ of the Brazilian manufacturing industry production in 2014 [5]. Consistent products sale has been one of the main drivers of the global alcoholic beverage market growth. Factors such as globalization, technological advancement, and deregulation of the most diverse economic sectors have profoundly altered the beverage market in Brazil in recent years, causing per capita consumption of beverages to increase, providing a series of business opportunities to companies and strong competition in the sector. These changes require increasing professionalization, particularly about the distribution of products and the optimization of production processes [6].

Shochu is a typical Japanese distillate with an alcoholic strength of about $25 \% \mathrm{~V} \cdot \mathrm{v}^{-1}$ that can be obtained from the fermentation of various raw materials such as rice, barley, and sweet potato, and subsequent distillation [7]. The consumption of shochu has a significant share of the Japanese market (10.6\%), being more consumed than sake (6.8\%) and whiskey (1.3\%) [8].

The traditional process for making sweet potato shochu is described by Yoshizaki and coauthors [9]. The first fermentation lasts five days and the second fermentation nine days, totalizing 14 days of processing. In the production of shochu, a solid culture of fungi called koji is used. Although maintaining the tradition of the Asian countries, the use of yellow koji (made with Aspergillus oryzae) ends up making the productive process slow and with a high risk of contamination.

In order to ensure distillate identity and quality standards as well as consumer safety, the limits of shochu components are outlined in Brazilian legislation, regulated by Ministério da Agricultura, Pecuária e Abastecimento (MAPA) [10]. These values are shown in Table 1.

Table 1. Brazilian legislation for shochu.

\begin{tabular}{|c|c|c|}
\hline Component & Minimum & Maximum \\
\hline Methyl alcohol (mg/100 mL anhydrous alcohol) & - & 20 \\
\hline Volatile acidity, in acetic acid (mg/100 mL anhydrous alcohol) & - & 100 \\
\hline $\begin{array}{l}\text { Higher alcohols ( } n \text {-propyl alcohol }+ \text { iso-butyl alcohol }+ \text { isoamyl alcohol) }(\mathrm{mg} / 100 \mathrm{~mL} \\
\text { anhydrous alcohol) }\end{array}$ & - & 200 \\
\hline Aldehydes, in acetic aldehyde (mg/100 mL anhydrous alcohol) & - & 20 \\
\hline Coefficient of congeners* (mg/100 mL anhydrous alcohol) & 200 & 500 \\
\hline Esters, in ethyl acetate (mg/100 mL anhydrous alcohol) & - & 200 \\
\hline Alcoholic graduation $\left(\% \mathrm{v} \cdot \mathrm{v}^{-1}\right.$ at $\left.20^{\circ} \mathrm{C}\right)$ & 15 & 35 \\
\hline Furfural + hydroxymethylfurfural (HMF) (mg/100 mL anhydrous alcohol) & - & 5 \\
\hline Sugar content (g/L) & - & 6 \\
\hline
\end{tabular}

*The coefficient of congeners is the sum of volatile acidity, aldehydes, total esters, higher alcohols, furfural and hydroxymethylfurfural.

There are reports of new alternatives aiming the improvement of the alcoholic beverage production process, such as the use of yeast cells immobilized in wine production and genetic modifications in yeasts to 
improve the fermentative properties of beer $[11,12]$. Also, studies are looking for more economical alternatives of malt adjuvants for the beer production process and the production of new alcoholic beverages, such as gluten-free beer [13,14], brandy of orange liquor using brewer's yeast from the brewing industry, and fermented and distilled beverages from whey protein [6].

In the case of amylaceous alcoholic beverages, recent reports of alternative processes of Chinese rice wine production have been reported, with new pretreatment techniques replacing the rice cooking stage $[15,16]$, use of different microorganisms, immobilized or not, and optimization of the fermentative stage and reforms in sterilization technology [15]. Wei and coauthors [16] concluded that, compared to traditional manufacturing technology, pre-treatment techniques that replace the cooking step of rice save water resources and reduce environmental pollution. Jiao and coauthors [15] states that innovation brings challenges and opportunities to the Chinese rice wine market, not only because it is associated with health, nutrition, safety, and palatability, but also because of the possibility of large-scale production due to energy and time savings, convenience, high efficiency, sanitation, and hygiene.

In this way, it is possible to notice the importance of alternative processes for producing alcoholic beverages with higher applied technology and the elimination of rudimentary steps. It can lead to a greater yield of alcoholic fermentation, reduction of costs and production time, besides providing differentiated consumption options, bringing benefits for both the industry and the final consumer.

Previous studies in our group (GIMSCOP) have improved the process of using sweet potato on ethanol production $[17,18]$. Schweinberger [19] showed that it is better to let sweet potatoes ripen for a specified time than to process them soon after harvest, with a maximum value of ethanol production and conversion efficiency achieved at 25 days after harvest. Thus, rotting sweet potatoes, a market residue, can be used for ethanol production. Besides, there are still the sweet potato harvest residues, which are crops with imperfections considered unsuitable for sale, but also suitable for producing ethanol.

In this context, considering the high productivity of sweet potato in Brazil, there is a great opportunity to add value to this waste raw material through the production and commercialization of a sweet potato distillate similar to shochu in the country, but with a production process that is faster and with less contamination risk, aiming to reduce costs and make the final product more competitive in the market.

The economic analysis of the proposed process has already been evaluated [20], bringing an important result not only as a technological alternative but also as a reduction of production costs. The main objective of this work is to study the technical viability of the alternative process, based on the enzymatic process of fuel ethanol production from sweet potato studied in our research group, with some modifications, aiming the production of distilled beverage from sweet potato waste. Also, the influence of the use of enzymes on product composition will be investigated.

\section{MATERIAL AND METHODS}

The experimental procedures were carried out at Laboratório de Controle e Integração de Processos (LACIP) of Chemical Engineering Department from Federal University of Rio Grande do Sul (UFRGS), Porto Alegre, Brazil. All experiments and analyses were performed in triplicate.

\section{Material}

The laboratory glassware used was previously autoclaved at 1 bar and $121^{\circ} \mathrm{C}$ for 15 minutes.

\section{Sweet potato}

Sweet potatoes with cream peel and cream pulp were purchased in a local market in the city of Porto Alegre, RS, Brazil.

\section{Reagents}

The reagents used in the experiments were the following: anhydrous dextrose P.A., glycerin P.A., ethyl acetate UV/HPLC, and n-propyl alcohol P.A. from Dinâmica Química Contemporânea Ltda; D-fructose (levulose), hydrochloric acid P.A., dry methyl alcohol P.A. (methanol) from Vetec Química Fina; absolute ethyl alcohol P.A., and potassium metabisulfite P.A. from Synth; glacial acetic acid 99.8\% P.A., iso-butyl alcohol P.A., isoamyl alcohol P.A., pure anhydrous acetaldehyde P.A., and furfural P.A. from Neon; 5(Hydroxymethyl) furfural from Sigma-Aldrich. 
Enzymes

It was studied to replace koji by the enzyme Stargen 002, a commercial mixture of the Genencor brand manufactured by DuPont, containing Aspergillus kawachi alpha-amylase expressed in Trichoderma reesei and $T$. reesei glucoamylase. Instead of koji, these enzymes were used to perform the hydrolysis of sweet potato starch, aiming to reduce the time required for hydrolysis and fermentation, reducing the risk of contamination and increasing the effectiveness. Pectinex Ultra AFP pectinase enzyme, supplied by LNF Latin America, was used to reduce the viscosity of the medium.

Yeasts

Three types of yeast were tested: Saccharomyces cerevisiae Angel Thermal Resistance Alcohol Yeast, S. cerevisiae var. Bayanus Lalvin DV10, and S. cerevisiae var. bayanus Lalvin EC1118, provided by LNF Latin America.

\section{Physicochemical analysis}

Moisture and total reducing sugars content were determined for all the sweet potato samples before their use. The moisture analysis was performed by oven drying at $105^{\circ} \mathrm{C}$ to constant weight [21]. The quantification of total reducing sugars was done through acid hydrolysis of the sweet potato starch, according to Schweinberger [17], followed by HPLC analysis. Briefly, $2 \mathrm{~g}$ of fresh sweet potato was crushed and homogenized in a $2 \mathrm{~mm}$ sieve. $25 \mathrm{~mL}$ of distilled water and $1 \mathrm{~mL}$ of hydrochloric acid were added. The solution was autoclaved at $1 \mathrm{bar}$ and $121^{\circ} \mathrm{C}$ for $2 \mathrm{~h}$. The mixture was neutralized with $10 \%(\mathrm{v} / \mathrm{v})$ sodium hydroxide solution to $\mathrm{pH}$ 3.5-4.0, diluted and filtered. The collected samples were frozen for later chromatographic analysis.

\section{Fermentation}

The fermentation process was performed according to Schweinberger [22], with some changes (Figure 1). The sweet potato was steamed until it reached $76^{\circ} \mathrm{C}$, cooled and crushed. $\mathrm{pH} 4$ buffer solution of citric acid and sodium citrate and potassium metabisulfite $0.15 \mathrm{~g} . \mathrm{L}^{-1}$ solution were prepared. To $240 \mathrm{~g}$ of ground sweet potato were added $140 \mathrm{~mL}$ of buffer solution, $20 \mathrm{~mL}$ of potassium metabisulfite solution, 240 $\mu \mathrm{l}$ of Stargen $002,24 \mu \mathrm{L}$ of pectinase and $0.8 \mathrm{~g}$ of yeast. The mash was fermented in a shaker at $30^{\circ} \mathrm{C}$ and $160 \mathrm{rpm}$ for 24 hours. Broth samples were centrifuged at $1372 \mathrm{G}$-force during 10 minutes. The supernatants were collected, filtered with $0.20 \mu \mathrm{m}$ nylon membrane and frozen. 


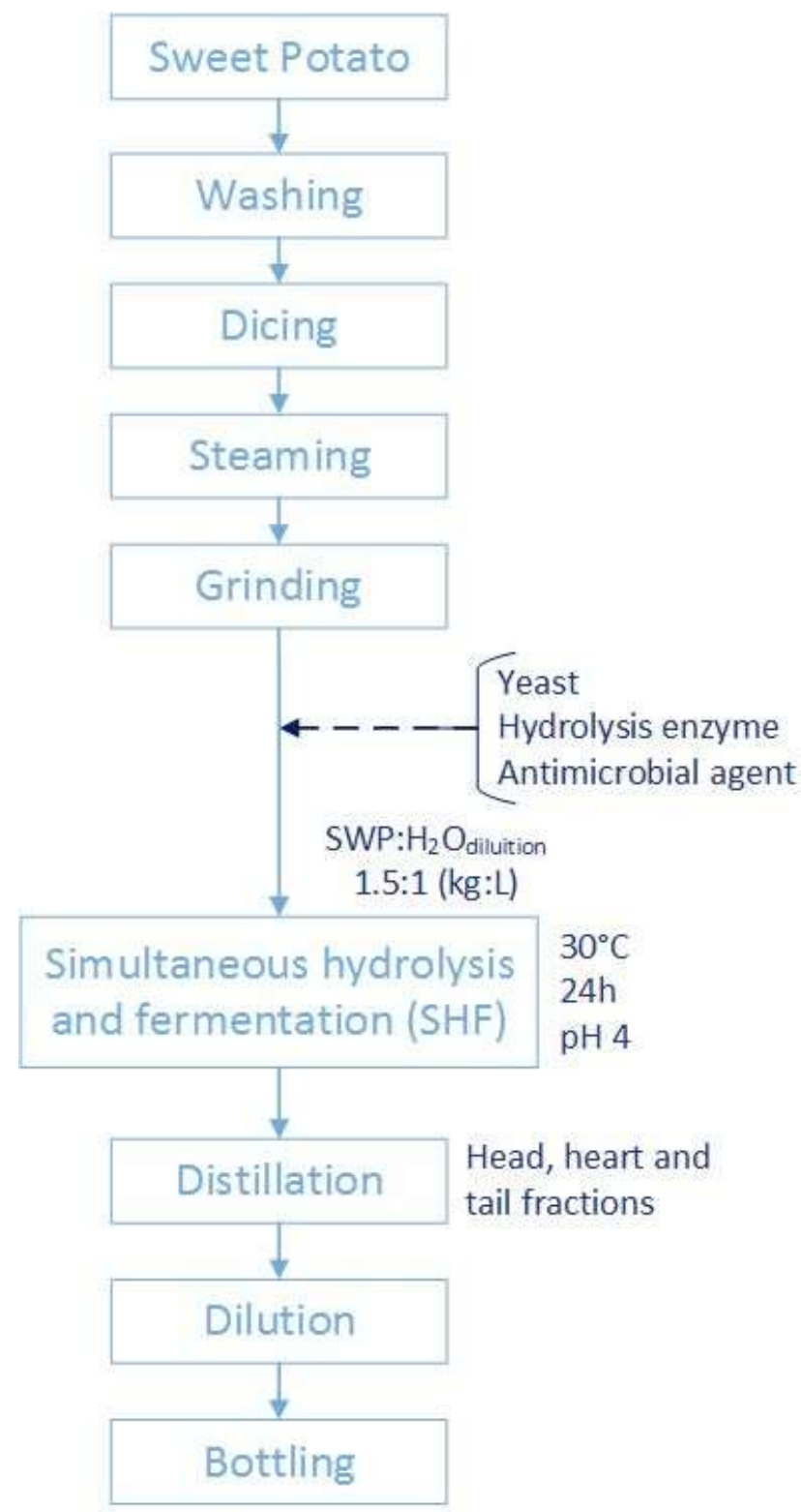

Figure 1. Distilled beverage alternative production process.

The theoretical ethanol content formed in the fermentation ( $\mathrm{x}_{\mathrm{et}, \text { theor }}$ ) can be calculated by Equation 1, as deduced in Schweinberger [23], as follows:

$$
x_{e t, t h e o r}\left(\%, v \cdot v^{-1}\right)=\frac{92 .\left(T R S_{s w p} \cdot x_{c_{-} s w p}\right)}{142.02+1.4202 .\left(x_{m_{-} s w p} \cdot x_{c_{-} s w p}\right)+0.778 .\left(T R S_{s w p} \cdot x_{s w p}\right)},
$$

where: TRS is the total reducing sugars; $x_{c}$ is the concentration; $x_{m}$ is the moisture content; subscript "swp" corresponds to sweet potato.

Since $x_{\text {et,exp }}$ is the experimental ethanol content formed in the fermentation, the experimental yield of the fermentation $\left(\mathrm{Y}_{\exp }\right)$ is calculated by Equation 2:

$$
Y_{\text {exp }} \quad(\%)=\frac{x_{e t, e x p}}{x_{e t, t h e o r}} \times 100 .
$$

\section{Distillation}

The distillation was carried out using a batch distillation apparatus with a $1 \mathrm{~L}$ reservoir, equipped with a $24 \times 600 \mathrm{~mm}$ column packed with 7×15 mm Raschig rings (Figure 2). 


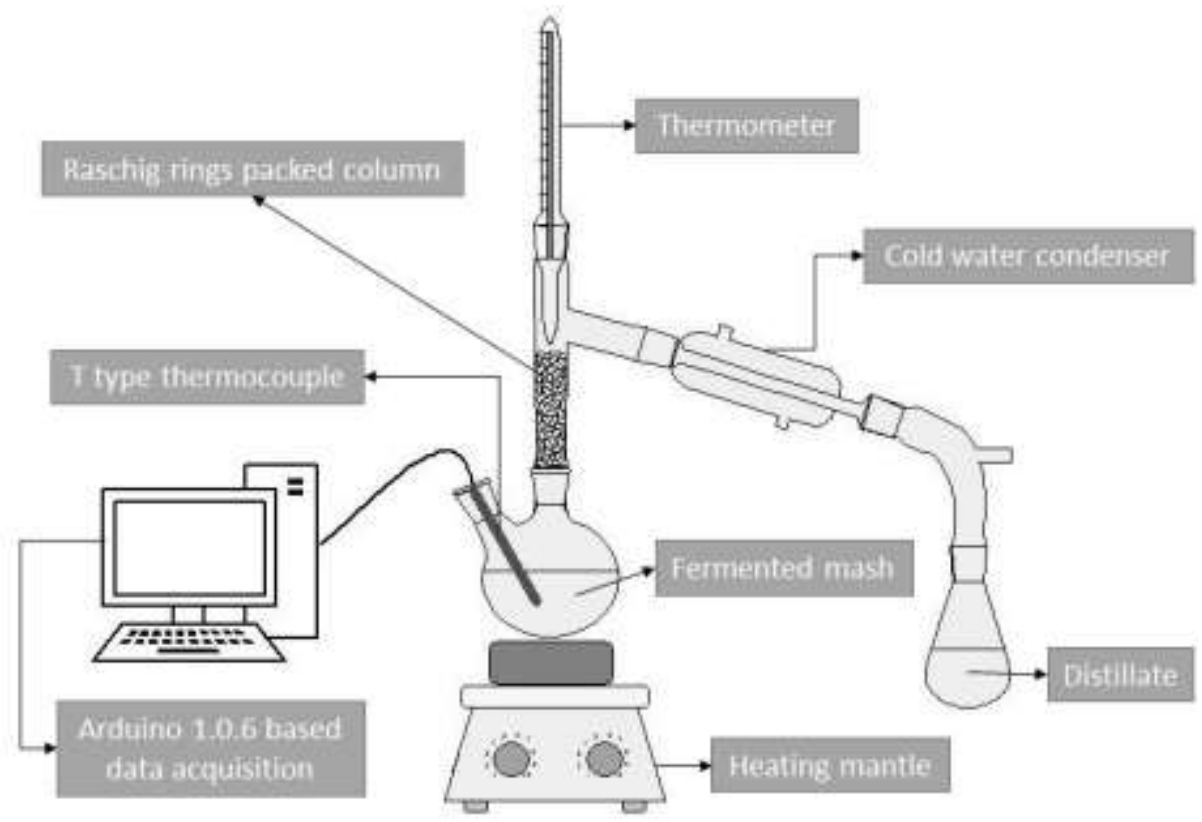

Figure 2. Distillation apparatus with Raschig rings packing column.

The temperature in the flask was monitored by T-type thermocouple with mineral insulation threaded to the side of the flask and monitored during the distillation in the Arduino 1.0.6 software. Also, the temperature was monitored at the top of the column using a thermometer. The distillate was condensed in a straight condenser with tap water circulation at room temperature and collected at the end of the system.

The alcohol content of the distillate was monitored using a portable digital refractometer, and checked by a previously constructed ethanol calibration curve with concentration ranging from 0 to $45 \%\left(v^{-1} v^{-1}\right)$ ethanol solution at room temperature.

It is known that for cachaça, a distilled spirit made from fermented sugarcane juice typical of Brazil, the head fraction corresponds to the collection of $5 \%$, the heart represents $80 \%$ and the tail corresponds to $15 \%$ of the total volume of the distillate [24]. Three distillate fractions were separated according to their alcohol content: head (up to $\left.50 \% \mathrm{v} \cdot \mathrm{v}^{-1}\right)$, heart $\left(50-38 \%{\left.\mathrm{v} . \mathrm{v}^{-1}\right)}^{-}\right.$and tail $\left(38-10 \% \mathrm{v} \cdot \mathrm{v}^{-1}\right)$ [25]. The samples were diluted and filtered with a $0.20 \mu \mathrm{m}$ nylon membrane for further analysis. Before the chromatographic analysis, all samples remained for 10 minutes in an ultrasonic bath (Unique USC $1600 \mathrm{~A} 40 \mathrm{kHz}$ ) to eliminate bubbles.

\section{Chromatographic Methods}

\section{High-Performance Liquid Chromatography (HPLC)}

The determination of glucose, fructose, ethanol, glycerol, acetic acid, acetaldehyde, methanol, furfural, and hydroxymethylfurfural was performed by high-performance liquid chromatography (HPLC) using Agilent Technologies 1260 Infinity II chromatograph equipped with Agilent Hi-Plex H column, according to methods applied by Ball and coauthors [26]. Isocratic milli-Q water was used as mobile phase at a flow rate of 0.6 $\mathrm{mL} . \mathrm{min}^{-1}$; the column temperature was $60^{\circ} \mathrm{C}$; the detector used was RID (Refractive Index Detector) at $55^{\circ} \mathrm{C}$ and the volume of sample injected was $20 \mu \mathrm{L}$.

\section{Gas Chromatography (GC)}

The determination of $n$-propyl alcohol, iso-butyl alcohol, isoamyl alcohol, and ethyl acetate was performed by gas chromatography on a SHIMADZU GC-2014 chromatograph, with manual injection, flame ionization detector (FID), Elite-WAX column with stationary phase polyethylene glycol $(30 \mathrm{~m} \times 0.25 \mathrm{~mm} \times$ $0.25 \mathrm{~mm}$ ), according to the method employed by Vilela and coauthors [27]. The temperature was $150^{\circ} \mathrm{C}$ for the injector and the detector. The temperature program of the column was $60^{\circ} \mathrm{C}$ for 2.5 minutes, increasing at a rate of $2^{\circ} \mathrm{C} \cdot \mathrm{min}^{-1}$ to $80^{\circ} \mathrm{C}$, where it remained for 2 minutes. The volume of the sample injected was $1 \mu \mathrm{L}$, and the split rate was 1:30. Nitrogen was used as a carrier gas; hydrogen and synthetic air were used for the formation of the flame. The pressure was $103.4 \mathrm{kPa}$, and the linear velocity was $33.5 \mathrm{~cm} . \mathrm{s}^{-1}$. 


\section{Fourier-Transform Infrared Spectroscopy (FTIR)}

Infrared analysis was performed to identify similarities and differences between the distillate produced and the commercial shochu. The infrared region of the electromagnetic spectrum is divided by convenience into three sub-regions according to the wavelength range: NIR (near-infrared region, $\sim 14000-4000 \mathrm{~cm}^{-1}$ ), MIR (mid-infrared region, $\sim 4000-400 \mathrm{~cm}^{-1}$ ), and FIR (far-infrared region, $\sim 400-10 \mathrm{~cm}^{-1}$ ). MIR is used to study fundamental vibrations and associated rotational-vibrational structures. This region is the most widely used to study organic functional groups, such as the component molecules of alcoholic beverages [28]. MIR spectrum was collected in the mid-infrared region of $4000-650 \mathrm{~cm}^{-1}$ using a PerkinElmer Frontier FT-NIR spectrometer, equipped with Universal Attenuated Total Reflectance (UATR) analysis module. The transmittance spectra were recorded at a spectral resolution of $16 \mathrm{~cm}^{-1}$. Each spectrum was an average of 16 scans.

\section{Principal Component Analysis (PCA)}

For a better interpretation of the results obtained for the compounds analyzed in the samples of sweet potato distillate, chemometric treatment using principal component analysis (PCA) with the aid of the Python 2.7 software was performed using the scikit-learn package. Both tools are completely open-source. The PCA method projects multivariate data into a smaller space, reducing the dimensionality of the original space in a new axis system called principal components (PC) [29,30]. The data matrix is decomposed into a product of two matrices, called scores and weights or loadings. The scores indicate the relationship between the samples and the weights the relationship between the variables [29]. The purpose of PCA is to find relationships between different parameters and detection of clusters in samples or variables [31]. The PCA was applied to separate the sweet potato distillate samples according to the results of FTIR spectra.

\section{Statistical analysis}

Statistical analysis was carried out with Statistica 64 software (academic license). The results were presented as means \pm SD (standard deviations). Differences in the compounds of the beverage fractions (head, heart, and tail) produced by three types of yeast were analyzed by a One-Way Analysis of Variance (ANOVA) together with the Tukey's test. Differences reaching a minimum confidence level of $95 \%(p<0.05)$ were considered as being statistically significant.

\section{RESULTS AND DISCUSSION}

The total sugar content of the sweet potato with cream peel and cream pulp was $26.93 \pm 0.86 \%$ and moisture content was $68.16 \pm 0.38 \%$. The theoretical ethanol content that should be formed $(11.66 \%)$ is calculated using equation (1), and then the experimental yield of the fermentation $\left(\mathrm{Y}_{\exp }\right)$ is calculated by equation (2). The experimental ethanol content formed in the fermentation process was $8.59 \pm 0.10\left(\% \mathrm{~V}^{-1} \mathrm{v}^{-1}\right.$,

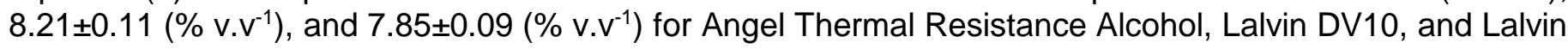
EC1118 yeasts, respectively.

The experimental yield of alcoholic fermentation was higher using Angel Thermal Resistance Alcohol (73.65\%), followed by Lalvin DV10 (70.39\%), and Lalvin EC1118 (67.31\%). Due to the formation of fewer byproducts of the fermentation, such as glycerol (not detected by HPLC), and to the non-occurrence of contamination by acetic bacteria, verified by the absence of acetic acid in the fermented, a great yield of alcoholic fermentation was reached. Similar results were achieved by Swain and coauthors [32], that reported a fermentation yield of $72 \%$ using sweet potato flour as biomass.

Additionally, the process requires fewer steps and is faster, taking only 1 day, while the traditional method of shochu production takes 14 days.

Using the distillation system installed, shown in Figure 2, a temperature gradient was observed in the column, which reveals the steam enrichment mechanism in the more volatile components. When reaching a certain point in the column, the steam coming from lower positions, warmer, undergoes partial condensation. The liquid flows into lower positions and the steam permeates the packing to higher points; the process is repeated several times. In this way, it is possible to carry out a better separation of the components of the distillate.

The desired distillate fraction cuts, with head (up to $50 \% \mathrm{v} \cdot \mathrm{v}^{-1}$ ), heart (50 to $38 \%{\mathrm{v} . \mathrm{v}^{-1}}^{-1}$ ), and tail (38 to $10 \%{\mathrm{~V} . \mathrm{V}^{-1}}^{-1}$ were successfully performed. Santiago and coauthors [33] also performed fraction cuts at similar 
ethanol concentrations. The results of the chromatographic analysis of these three fractions are shown in Table 2.

Table 2. Results of the chromatographic analysis of the sweet potato distillate fractions produced by the new route (with pectinase addition).

\begin{tabular}{|c|c|c|c|c|c|c|c|c|c|}
\hline \multirow{2}{*}{ Component ${ }^{*}$} & \multicolumn{3}{|c|}{ Head } & \multicolumn{3}{|c|}{ Heart } & \multicolumn{3}{|c|}{ Tail } \\
\hline & $\mathrm{TH}^{1}$ & $\mathrm{DV}^{2}$ & $\mathrm{EC}^{3}$ & $\mathrm{TH}^{1}$ & $\mathrm{DV}^{2}$ & $\mathrm{EC}^{3}$ & $\mathrm{TH}^{1}$ & $\mathrm{DV}^{2}$ & $\mathrm{EC}^{3}$ \\
\hline $\begin{array}{l}\text { Methyl } \\
\text { alcohol }^{4}\end{array}$ & $\begin{array}{l}239.88^{b} \\
\pm 13.75\end{array}$ & $\begin{array}{c}347.00^{\mathrm{ac}} \\
\pm 19.82\end{array}$ & $\begin{array}{c}293.63^{b c} \\
\pm 15.56\end{array}$ & $\begin{array}{l}384.40^{\mathrm{a}} \\
\pm 20.37\end{array}$ & $\begin{array}{c}302.64^{\mathrm{b}} \\
c \\
\pm 17.25\end{array}$ & $\begin{array}{r}380.89^{a} \\
\pm 18.36\end{array}$ & $\begin{array}{l}579.32^{\mathrm{e}} \\
\pm 28.54\end{array}$ & $\begin{array}{l}396.38^{a} \\
\pm 26.73\end{array}$ & $\begin{array}{l}485.15^{d} \\
\pm 32.96\end{array}$ \\
\hline $\begin{array}{l}\text { Volatile } \\
\text { acidity }^{4} \quad \text { (in } \\
\text { acetic acid) }\end{array}$ & $N D^{6}$ & $\mathrm{ND}^{6}$ & $\mathrm{ND}^{6}$ & $N D^{6}$ & $N D^{6}$ & $N D^{6}$ & $N D^{6}$ & $N D^{6}$ & $N D^{6}$ \\
\hline $\begin{array}{l}N \text {-propyl } \\
\text { alcohol }^{4}\end{array}$ & $\begin{array}{l}24.71^{\mathrm{b}} \\
\pm 2.28\end{array}$ & $\begin{array}{l}34.42^{\mathrm{a}} \\
\pm 1.83\end{array}$ & $\begin{array}{l}33.46^{\mathrm{a}} \\
\pm 2.61\end{array}$ & $\begin{array}{c}27.48^{\mathrm{bc}} \\
\pm 1.47\end{array}$ & $\begin{array}{c}31.14^{\mathrm{ac}} \\
\pm 2.04\end{array}$ & $\begin{array}{l}33.70^{\mathrm{a}} \\
\pm 1.75\end{array}$ & $\begin{array}{c}25.54^{\mathrm{bc}} \\
\pm 1.59\end{array}$ & $\begin{array}{l}36.05^{\mathrm{a}} \\
\pm 1.98\end{array}$ & $\begin{array}{l}35.80^{\mathrm{a}} \\
\pm 1.96\end{array}$ \\
\hline $\begin{array}{l}\text { Iso-butyl } \\
\text { alcohol }^{4}\end{array}$ & $\begin{array}{c}20.49^{\mathrm{ab}} \\
\pm 1.42\end{array}$ & $\begin{array}{c}22.33^{b} \\
\pm 1.18\end{array}$ & $\begin{array}{l}15.53^{\mathrm{a}} \\
\pm 1.07\end{array}$ & $\begin{array}{l}40.25^{\circ} \\
\pm 2.19\end{array}$ & $\begin{array}{c}44.88^{\mathrm{cd}} \\
\pm 2.51\end{array}$ & $\begin{array}{c}18.76^{\mathrm{ab}} \\
\pm 1.12\end{array}$ & $\begin{array}{l}46.16^{d} \\
\pm 2.86\end{array}$ & $\begin{array}{c}42.46^{\mathrm{cd}} \\
\pm 2.29\end{array}$ & $\begin{array}{l}29.70^{e} \\
\pm 2.09\end{array}$ \\
\hline $\begin{array}{l}\text { Isoamyl } \\
\text { alcohol }^{4}\end{array}$ & $\begin{array}{c}102.67^{\mathrm{a}} \\
\pm 5.75\end{array}$ & $\begin{array}{c}119.55^{\mathrm{a}} \\
\pm 8.07\end{array}$ & $\begin{array}{c}102.24^{\mathrm{a}} \\
\pm 7.54\end{array}$ & $\begin{array}{c}112.13^{\mathrm{a}} \\
\pm 6.22\end{array}$ & $\begin{array}{c}108.42^{\mathrm{a}} \\
\pm 6.68\end{array}$ & $\begin{array}{c}113.52^{\mathrm{a}} \\
\pm 6.11\end{array}$ & $\begin{array}{c}118.84^{\mathrm{a}} \\
\pm 7.93\end{array}$ & $\begin{array}{c}111.23^{\mathrm{a}} \\
\pm 6.96\end{array}$ & $\begin{array}{c}108.56^{\mathrm{a}} \\
\pm 6.53\end{array}$ \\
\hline $\begin{array}{l}\text { Higher } \\
\text { alcohols }{ }^{45}\end{array}$ & $\begin{array}{l}147.87^{a} \\
\pm 11.89\end{array}$ & $\begin{array}{c}176.30^{\mathrm{ab}} \\
\pm 14.63\end{array}$ & $\begin{array}{c}151.23^{\mathrm{ab}} \\
\pm 12.70\end{array}$ & $\begin{array}{c}179.86^{\mathrm{ab}} \\
\pm 13.57\end{array}$ & $\begin{array}{c}184.44^{a} \\
b \\
\pm 16.31\end{array}$ & $\begin{array}{c}165.98^{\mathrm{ab}} \\
\pm 14.95\end{array}$ & $\begin{array}{l}190.54^{\mathrm{b}} \\
\pm 15.82\end{array}$ & $\begin{array}{c}189.74^{\mathrm{ab}} \\
\pm 15.76\end{array}$ & $\begin{array}{c}174.06^{\mathrm{ab}} \\
\pm 15.49\end{array}$ \\
\hline $\begin{array}{l}\text { Aldehydes }{ }^{4} \\
\text { (in acetic } \\
\text { aldehyde) }\end{array}$ & $N D^{6}$ & $\mathrm{ND}^{6}$ & $\mathrm{ND}^{6}$ & $N D^{6}$ & $N D^{6}$ & $N D^{6}$ & $N D^{6}$ & $N D^{6}$ & $N^{6}$ \\
\hline $\begin{array}{l}\text { Coefficient of } \\
\text { congeners }\end{array}$ & $\begin{array}{l}275.94^{\mathrm{a}} \\
\pm 21.49\end{array}$ & $\begin{array}{c}297.49^{\mathrm{a}} \\
\pm 27.37\end{array}$ & $\begin{array}{l}288.47^{\mathrm{a}} \\
\pm 26.83\end{array}$ & $\begin{array}{l}314.57^{a} \\
\pm 28.94\end{array}$ & $\begin{array}{l}330.51^{\mathrm{a}} \\
\pm 32.35\end{array}$ & $\begin{array}{l}305.10^{\mathrm{a}} \\
\pm 28.67\end{array}$ & $\begin{array}{l}341.94^{a} \\
\pm 31.80\end{array}$ & $\begin{array}{l}344.29^{a} \\
\pm 33.39\end{array}$ & $\begin{array}{l}318.03^{a} \\
\pm 30.48\end{array}$ \\
\hline $\begin{array}{l}\text { Esters }^{4} \quad \text { (in } \\
\text { ethyl acetate) }\end{array}$ & $\begin{array}{c}128.07^{\mathrm{ac}} \\
\pm 7.43\end{array}$ & $\begin{array}{c}121.19^{c} \\
\pm 7.88\end{array}$ & $\begin{array}{c}137.24^{\mathrm{abc}} \\
\pm 8.78\end{array}$ & $\begin{array}{c}134.71^{\mathrm{abc}} \\
\pm 8.02\end{array}$ & $\begin{array}{c}146.07^{a} \\
b \\
\pm 7.45\end{array}$ & $\begin{array}{c}139.12^{\mathrm{abc}} \\
\pm 8.24\end{array}$ & $\begin{array}{l}151.40^{\mathrm{ab}} \\
\pm 9.69\end{array}$ & $\begin{array}{c}154.55^{\mathrm{b}} \\
\pm 8.96\end{array}$ & $\begin{array}{c}143.97^{\mathrm{abc}} \\
\pm 9.71\end{array}$ \\
\hline $\begin{array}{l}\text { Alcoholic } \\
\text { graduation } \\
\left(\% \mathrm{v} \cdot \mathrm{v}^{-1} \text { at }\right. \\
\left.20^{\circ} \mathrm{C}\right)\end{array}$ & $\begin{array}{c}66.99^{\text {de }} \\
\pm 3.75\end{array}$ & $\begin{array}{l}60.14^{d} \\
\pm 3.11\end{array}$ & $\begin{array}{l}71.63^{\mathrm{e}} \\
\pm 3.87\end{array}$ & $\begin{array}{l}38.88^{\mathrm{a}} \\
\pm 2.02\end{array}$ & $\begin{array}{l}40.77^{\mathrm{a}} \\
\pm 2.13\end{array}$ & $\begin{array}{l}39.31^{\mathrm{a}} \\
\pm 2.72\end{array}$ & $\begin{array}{c}22.83^{\mathrm{bc}} \\
\pm 1.28\end{array}$ & $\begin{array}{l}23.78^{\mathrm{c}} \\
\pm 1.24\end{array}$ & $\begin{array}{l}16.26^{\mathrm{b}} \\
\pm 1.09\end{array}$ \\
\hline $\begin{array}{l}\text { Furfural } \\
\text { HMF }^{4}\end{array}$ & $\mathrm{ND}^{6}$ & $\mathrm{ND}^{6}$ & $\mathrm{ND}^{6}$ & $\mathrm{ND}^{6}$ & $N D^{6}$ & $N D^{6}$ & $\mathrm{ND}^{6}$ & $N D^{6}$ & $N D^{6}$ \\
\hline $\begin{array}{l}\text { Sugar } \\
\text { content }(g / L)\end{array}$ & $N D^{6}$ & $\mathrm{ND}^{6}$ & $N D^{6}$ & $N D^{6}$ & $N D^{6}$ & $N D^{6}$ & $N D^{6}$ & $N D^{6}$ & $N D^{6}$ \\
\hline
\end{tabular}

* Mean values that do not share the same letter in each component's line are significantly different, according to Tukey test with $95 \%$ confidence $(p<0.05)$.

1 Yeast Angel Thermal Resistance Alcohol.

2 Yeast Lalvin DV10.

3 Yeast Lalvin EC1118.

${ }^{4}$ In $\mathrm{mg} / 100 \mathrm{~mL}$ anhydrous alcohol.

${ }^{5}$ Higher alcohols $=$ n-propyl alcohol + iso-butyl alcohol + isoamyl alcohol.

${ }^{6} \mathrm{ND}=$ not detected.

The methyl alcohol component presented difficult separation, being distributed throughout the fractions of the distillate. Small amounts of methanol may be present in alcoholic beverages, formed as a by-product of the fermentative process. Since the limit of the Brazilian legislation for methanol equals to twenty milligrams per hundred milliliters of anhydrous alcohol, it is observed that the methanol content is above the limit for all the fractions of distillates, in the results of all yeasts. It makes the distillate unfit for consumption because of the high toxicity of methanol, which can be harmful to health. Blinder and coauthors [34] state that the amount of methanol may increase due to inadequate storage conditions and also by the presence of pectinases and other enzymes. Badolato and coauthors [35] report that, in small amounts, methanol can cause a headache, dizziness, nausea, and vomiting. Consumption of $20 \mathrm{~mL}$ can cause blindness while $60 \mathrm{~mL}$ is usually lethal if left untreated. All other compounds are within limits set by legislation. 
In the head fraction, the first to leave the distiller, the more volatile components such as esters and aldehydes are expected to be present in higher concentration. The acetic aldehyde compound was below the detection limit of the equipment, while for the esters the opposite behavior was observed. Higher concentrations of ethyl acetate were recorded in the tail fraction, followed by the heart, and finally the head. Thus, no efficient separation of the compounds occurred. In the case of a complex mixture, deviations from ideality occur, and the conditions necessary to obtain adequate separation of the compounds go beyond the evaluation of the boiling points and the resolution that the distillation apparatus offers.

In the tail fraction, the last to leave the pot, the compounds that remain are less volatile than ethyl alcohol such as organic acids and higher alcohols. Acetic acid was below the equipment limit of detection, whereas higher alcohols presented behavior as expected, being in higher concentrations in the tail fractions. Among the higher alcohols, the highest amount was isoamyl alcohol. In the sensory analysis performed in Yuan and coauthors [36], it was reported that samples of shochu with higher amounts of isoamyl alcohol presented a more bitter taste.

The reflux occurs due to the condensation of steam inside the column, albeit less efficiently than the external reflux. The height of the column and the packing provide a temperature gradient and flow resistance required for condensation and then reflux of distillate. Also, the packing allows a high contact area between the liquid and the vapor, facilitating the transfer of heat and mass.

To identify the possible causes for the high content of methanol, and knowing that the amount of methanol of wine is higher when pectinolytic enzymes are applied [25], it was decided to suppress the pectinase.

Sweet potatoes from different crops show differences in composition. Kolbe and coauthors [37] state that the size of sweet potatoes affects their content of organic and inorganic components, including water, starch, sugars, and organic acids. For this reason, moisture analysis and acid hydrolysis of sweet potatoes were repeated in all experiments. In this one, acid hydrolysis of sweet potato resulted in a reducing sugar content of $31.66 \pm 0.24 \%$ and a moisture content of $66.25 \pm 0.08 \%$. Through equation (1), the theoretical ethanol content $\left(\mathrm{X}_{\mathrm{et}}\right)$ that should be produced is $12.58 \%$ and, afterward, the experimental yield of the fermentation $\left(\mathrm{Y}_{\text {exp }}\right)$ is calculated by equation (2). For the yeasts Angel Thermal Resistance Alcohol, Lalvin DV10, and Lalvin EC1118, the experimental ethanol content formed in the fermentation process was $6.78 \pm 0.03$ (\% V.V $\left.{ }^{1}\right), 6.50 \pm 0.04\left(\% v^{-1} v^{-1}\right)$, and $6.89 \pm 0.05\left(\% v \cdot v^{-1}\right)$, respectively.

The alcoholic fermentation yield was similar using the three types of yeast, being slightly higher for Lalvin EC1118 (54.75\%), followed by Angel Thermal Resistance Alcohol (53.88\%), and finally Lalvin DV10 (51.65\%). These values were about $20 \%$ lower than those obtained in the experiment performed with the addition of pectinase. Leonel and coauthors and Schweinberger $[19,38]$ concluded that the use of pectinase as a complementary enzyme to the amylases in the hydrolysis-saccharification process provides better yields to the process. These results indicate that the high viscosity of the medium and the incomplete disintegration of the sweet potato pieces, caused by the absence of pectinase, impair the progress of the fermentation process, causing a decrease in the yield of the alcoholic fermentation.

The separation of head, heart, and tail was performed as described in the previous section. The results of the chromatographic analysis are presented in Table 3. 
Table 3. Results of the chromatographic analysis of the sweet potato distillate fractions produced by the new route (without pectinase addition).

\begin{tabular}{|c|c|c|c|c|c|c|c|c|c|}
\hline \multirow{2}{*}{ Component $^{*}$} & \multicolumn{3}{|c|}{ Head } & \multicolumn{3}{|c|}{ Heart } & \multicolumn{3}{|c|}{ Tail } \\
\hline & $\mathrm{TH}^{1}$ & $\mathrm{DV}^{2}$ & $\mathrm{EC}^{3}$ & $\mathrm{TH}^{1}$ & $\mathrm{DV}^{2}$ & $\mathrm{EC}^{3}$ & $\mathrm{TH}^{1}$ & $\mathrm{DV}^{2}$ & $\mathrm{EC}^{3}$ \\
\hline $\begin{array}{l}\text { Methyl } \\
\text { alcohol }^{4}\end{array}$ & $\mathrm{ND}^{6}$ & $N^{6}$ & $\mathrm{ND}^{6}$ & $N^{6}$ & $N^{6}$ & $\mathrm{ND}^{6}$ & $N^{6}$ & $\mathrm{ND}^{6}$ & $\mathrm{ND}^{6}$ \\
\hline $\begin{array}{l}\text { Volatile } \\
\text { acidity }{ }^{4} \text { (in } \\
\text { acetic acid) }\end{array}$ & $\mathrm{ND}^{6}$ & $\begin{array}{l}0.76^{d} \\
\pm 0.03\end{array}$ & $\begin{array}{l}1.13^{\mathrm{e}} \\
\pm 0.05\end{array}$ & $\begin{array}{l}1.00^{\mathrm{a}} \\
\pm 0.04\end{array}$ & $\begin{array}{l}1.03^{\mathrm{a}} \\
\pm 0.04\end{array}$ & $N^{6}$ & $\begin{array}{l}0.61^{c} \\
\pm 0.02\end{array}$ & $\mathrm{ND}^{6}$ & $\begin{array}{r}0.17^{\mathrm{b}} \\
\pm 0.01\end{array}$ \\
\hline $\begin{array}{l}N \text {-propyl } \\
\text { alcohol }^{4}\end{array}$ & $\begin{array}{l}37.08^{\mathrm{e}} \\
\pm 1.67\end{array}$ & $\begin{array}{l}75.92^{\mathrm{b}} \\
\pm 4.25\end{array}$ & $\begin{array}{l}89.44^{c} \\
\pm 5.72\end{array}$ & $\begin{array}{l}23.38^{d} \\
\pm 1.40\end{array}$ & $\begin{array}{l}50.48^{a} \\
\pm 2.62\end{array}$ & $\begin{array}{l}53.13^{\mathrm{a}} \\
\pm 3.35\end{array}$ & $\begin{array}{l}54.62^{\mathrm{a}} \\
\pm 2.79\end{array}$ & $\begin{array}{l}78.41^{\mathrm{b}} \\
\pm 4.49\end{array}$ & $\begin{array}{l}91.56^{c} \\
\pm 5.16\end{array}$ \\
\hline $\begin{array}{l}\text { Iso-butyl } \\
\text { alcohol }^{4}\end{array}$ & $\begin{array}{c}24.01^{a} \\
\pm 1.25\end{array}$ & $\begin{array}{l}19.10^{d} \\
\pm 1.31\end{array}$ & $\begin{array}{l}19.09^{d} \\
\pm 1.01\end{array}$ & $\begin{array}{l}14.88^{c} \\
\pm 0.86\end{array}$ & $\begin{array}{l}10.33^{b} \\
\pm 0.52\end{array}$ & $\begin{array}{c}13.05^{\mathrm{bc}} \\
\pm 0.70\end{array}$ & $\begin{array}{c}27.52^{\mathrm{ae}} \\
\pm 1.58\end{array}$ & $\begin{array}{c}30.65^{\mathrm{e}} \\
\pm 1.66\end{array}$ & $\begin{array}{c}25.78^{a} \\
\pm 1.73\end{array}$ \\
\hline $\begin{array}{l}\text { Isoamyl } \\
\text { alcohol }^{4}\end{array}$ & $\begin{array}{c}83.45^{\mathrm{e}} \\
\pm 4.91\end{array}$ & $\begin{array}{l}51.83^{\mathrm{ac}} \\
\pm 3.11\end{array}$ & $\begin{array}{l}57.07^{a} \\
\pm 3.20\end{array}$ & $\begin{array}{l}56.24^{a} \\
\pm 3.27\end{array}$ & $\begin{array}{l}36.44^{\mathrm{b}} \\
\pm 2.33\end{array}$ & $\begin{array}{l}41.81^{\mathrm{bc}} \\
\pm 2.46\end{array}$ & $\begin{array}{l}97.87^{\dagger} \\
\pm 5.97\end{array}$ & $\begin{array}{l}81.84^{\text {de }} \\
\pm 4.62\end{array}$ & $\begin{array}{l}71.67^{d} \\
\pm 4.73\end{array}$ \\
\hline $\begin{array}{l}\text { Higher } \\
\text { alcohols }^{45}\end{array}$ & $\begin{array}{c}144.54^{\circ} \\
\pm 8.67\end{array}$ & $\begin{array}{c}146.85^{\circ} \\
\pm 9.52\end{array}$ & $\begin{array}{c}165.60^{\mathrm{ac}} \\
\pm 9.77\end{array}$ & $\begin{array}{l}94.50^{\mathrm{b}} \\
\pm 5.86\end{array}$ & $\begin{array}{l}97.25^{\mathrm{b}} \\
\pm 5.64\end{array}$ & $\begin{array}{c}107.99^{\mathrm{b}} \\
\pm 6.80\end{array}$ & $\begin{array}{l}180.01^{\mathrm{a}} \\
\pm 11.34\end{array}$ & $\begin{array}{l}190.90^{\mathrm{a}} \\
\pm 10.45\end{array}$ & $\begin{array}{l}189.01^{\mathrm{a}} \\
\pm 12.14\end{array}$ \\
\hline $\begin{array}{l}\text { Aldehydes }{ }^{4} \\
\text { (in acetic } \\
\text { aldehyde) }\end{array}$ & $\mathrm{ND}^{6}$ & $\mathrm{ND}^{6}$ & $\mathrm{ND}^{6}$ & $\mathrm{ND}^{6}$ & $N^{6}$ & $N^{6}$ & $\mathrm{ND}^{6}$ & $\mathrm{ND}^{6}$ & $N^{6}$ \\
\hline $\begin{array}{l}\text { Coefficient } \\
\text { of } \\
\text { congeners }\end{array}$ & $\begin{array}{l}280.85^{b} \\
\pm 16.85\end{array}$ & $\begin{array}{c}339.58^{\mathrm{a}} \\
\pm 15.29\end{array}$ & $\begin{array}{l}340.90^{\mathrm{a}} \\
\pm 18.61\end{array}$ & $\begin{array}{l}244.11^{\mathrm{b}} \\
\pm 14.06\end{array}$ & $\begin{array}{l}277.44^{\mathrm{b}} \\
\pm 14.37\end{array}$ & $\begin{array}{l}272.16^{\mathrm{b}} \\
\pm 13.84\end{array}$ & $\begin{array}{l}378.83^{a} \\
\pm 19.46\end{array}$ & $\begin{array}{l}388.14^{a} \\
\pm 20.15\end{array}$ & $\begin{array}{c}387.97^{a} \\
\pm 19.06\end{array}$ \\
\hline $\begin{array}{l}\text { Esters }^{4} \quad \text { (in } \\
\text { ethyl } \\
\text { acetate) }\end{array}$ & $\begin{array}{c}135.38^{\mathrm{c}} \\
\pm 8.19\end{array}$ & $\begin{array}{l}191.97^{\mathrm{ab}} \\
\pm 11.90\end{array}$ & $\begin{array}{c}173.67^{\text {bod }} \\
\pm 9.52\end{array}$ & $\begin{array}{c}148.33^{\mathrm{cd}} \\
\pm 8.31\end{array}$ & $\begin{array}{c}178.81^{\mathrm{ab}} \\
\pm 9.66\end{array}$ & $\begin{array}{c}163.83^{\text {bcd }} \\
\pm 9.15\end{array}$ & $\begin{array}{l}198.15^{a} \\
\pm 10.48\end{array}$ & $\begin{array}{l}197.24^{\mathrm{a}} \\
\pm 10.24\end{array}$ & $\begin{array}{l}198.59^{\mathrm{a}} \\
\pm 12.03\end{array}$ \\
\hline $\begin{array}{l}\text { Alcoholic } \\
\text { graduation } \\
\left(\% \text { v. } v^{-1}\right. \\
\left.\text { at } 20^{\circ} \mathrm{C}\right)\end{array}$ & $\begin{array}{l}54.62^{\mathrm{b}} \\
\pm 2.89\end{array}$ & $\begin{array}{c}58.60^{\mathrm{b}} \\
\pm 3.28\end{array}$ & $\begin{array}{l}54.84^{\mathrm{b}} \\
\pm 3.64\end{array}$ & $\begin{array}{l}36.61^{\mathrm{d}} \\
\pm 1.94\end{array}$ & $\begin{array}{l}29.99^{c} \\
\pm 1.71\end{array}$ & $\begin{array}{c}32.65^{\mathrm{cd}} \\
\pm 1.95\end{array}$ & $\begin{array}{l}12.56^{a} \\
\pm 0.68\end{array}$ & $\begin{array}{l}13.52^{\mathrm{a}} \\
\pm 0.74\end{array}$ & $\begin{array}{l}14.03^{\mathrm{a}} \\
\pm 0.83\end{array}$ \\
\hline $\begin{array}{l}\text { Furfural } \\
\text { HMF }^{4}\end{array}$ & $\begin{array}{c}0.93^{f} \\
\pm 0.04\end{array}$ & $\mathrm{ND}^{6}$ & $\begin{array}{l}0.50 \mathrm{e} \\
\pm 0.03\end{array}$ & $\begin{array}{l}0.28^{a} \\
\pm 0.01\end{array}$ & $\begin{array}{l}0.35^{\mathrm{b}} \\
\pm 0.02\end{array}$ & $\begin{array}{l}0.34^{\mathrm{ab}} \\
\pm 0.02\end{array}$ & $\begin{array}{l}0.06^{c} \\
\pm 0.03\end{array}$ & $N^{6}$ & $\begin{array}{l}0.20^{d} \\
\pm 0.01\end{array}$ \\
\hline $\begin{array}{l}\text { Sugar } \\
\text { content }(g / L)\end{array}$ & $\begin{array}{l}0.01^{\mathrm{a}} \\
\pm 0.00\end{array}$ & $\begin{array}{l}0.01^{\mathrm{a}} \\
\pm 0.00\end{array}$ & $\begin{array}{l}0.03^{b} \\
\pm 0.01\end{array}$ & $\begin{array}{l}0.01^{a} \\
\pm 0.00\end{array}$ & $\begin{array}{l}0.01^{\mathrm{a}} \\
\pm 0.00\end{array}$ & $\begin{array}{l}0.05^{c} \\
\pm 0.01\end{array}$ & $\begin{array}{l}0.01^{\mathrm{a}} \\
\pm 0.00\end{array}$ & $N^{6}$ & $N^{6}$ \\
\hline
\end{tabular}

* Mean values that do not share the same letter in each component's line are significantly different, according to Tukey test with $95 \%$ confidence $(p<0.05)$.

1 Yeast Angel Thermal Resistance Alcohol.

2 Yeast Lalvin DV10.

3 Yeast Lalvin EC1118.

4 In $\mathrm{mg} / 100 \mathrm{~mL}$ anhydrous alcohol.

5 Higher alcohols $=$ n-propyl alcohol + iso-butyl alcohol + isoamyl alcohol.

${ }^{6} \mathrm{ND}=$ not detected.

All compounds analyzed were within the limits of the current legislation. The methyl alcohol component was below the detection limit of the equipment. As the experimental conditions were identical to the previous item, except for the addition of pectinase, it is concluded that this enzyme is responsible for the high concentration of methanol formed in the previous results, caused by the hydrolysis of pectin. The results found are in agreement with those presented by Zhang and coauthors [39], that found that the use of pectinase enzyme significantly increased the methanol concentrations of apple distillates.

In order to identify the similarities and differences between the composition of the produced distilled (heart fraction) and the commercial shochu, FTIR analyses were performed. The result of the overlap of the MIR spectrum of the two beverages can be seen in Figure 3.

The FTIR spectrum of sweet potato distillates was dominated by the absorption bands of alcohol and water. The O-H stretch bands can be observed in the ranges of $3550-3100 \mathrm{~cm}^{-1}$ and $1750-1550 \mathrm{~cm}^{-1}$. The C$\mathrm{O}$ stretch band is in the range of $1100-1000 \mathrm{~cm}^{-1}$, and in the range $2980-2850 \mathrm{~cm}^{-1}$ there is $\mathrm{C}-\mathrm{H}$ stretch band. 
The bands of $\mathrm{C}-\mathrm{O}, \mathrm{C}-\mathrm{C}, \mathrm{CH}_{2}, \mathrm{CH}_{3}, \mathrm{C}-\mathrm{OH}, \mathrm{C}-\mathrm{H}$ and $\mathrm{C} \equiv \mathrm{N}$ can be observed in the range $1450-1150 \mathrm{~cm}^{-1}$. The band at $860 \mathrm{~cm}^{-1}$ is attributed to off-plane $\mathrm{C}-\mathrm{H}$ folds [40].

It is observed that all samples overlap showing peaks in the same absorption bands, only with a variation of intensity. Thus, it can be concluded that the composition of the sweet potato distillate produced by the alternative route without the addition of pectinase resembles the commercial shochu composition, concerning the components identified by the FTIR analysis.

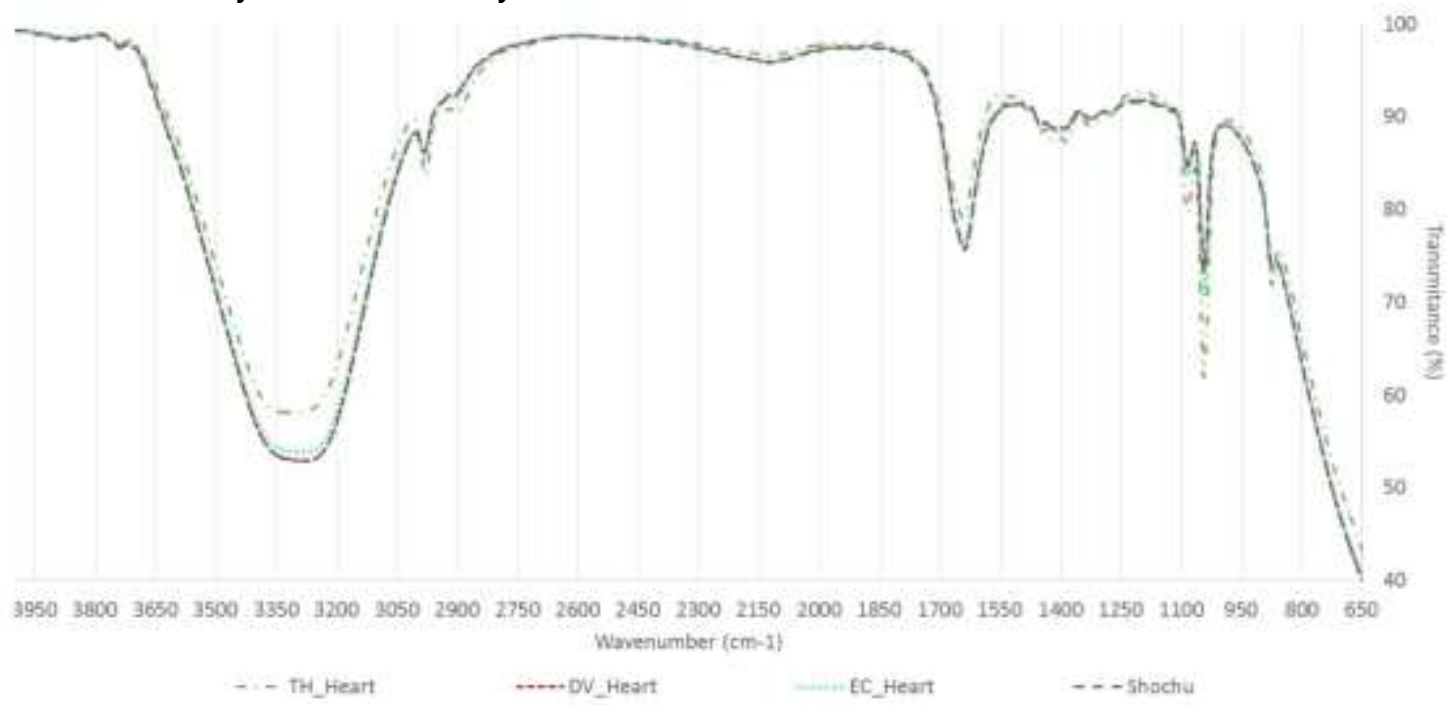

Figure 3. FTIR spectrum of the heart fraction of sweet potato distillates and shochu. TH, DV and EC refer to the yeasts Thermal Resistance Alcohol, Lalvin DV10 and Lalvin EC1118, respectively.

The resulting FTIR spectra were analyzed by means of PCA analysis, which allowed the identification of the clusters and the outliers. The normalized graph of principal components analysis can be visualized in Figure 4.



Figure 4. PC1 vs. PC2 normalized PCA of MIR spectrum. TH, DV and EC refer to the yeasts Thermal Resistance Alcohol, Lalvin DV10 and Lalvin EC1118, respectively.

From PCA it can be seen that $80.54 \%$ of the data variability can be described with only one main component, PC1, which is associated with ethanol (correlated) and water (uncorrelated), with samples containing higher ethanol contents with higher PC1 values. The PC2 component, which describes $15.91 \%$ of the data variation, is associated with variations in peaks due to changes in ethanol-water composition and hydrogen bonding. PC1 and PC2 together describe $96.45 \%$ of the variability of the spectra. Similar results were reported by Nordon and coauthors [41]. With the graphical analysis, it was also possible to verify some groupings of samples relative to the fractions of distillate collected in the process. Besides, it is found that the heart samples of the final product that used the yeasts Lalvin DV10 and Lalvin EC1118 were the closest to commercial shochu. 


\section{CONCLUSION}

The proposal to produce a sweet potato distillate similar to shochu by an alternative process was achieved, allowing a reduction in production time and reducing the risk of contamination.

The fermentation process time was reduced from 14 days to only one day and, in addition, there were no contamination problems.

The distillate produced and the commercial shochu presented the same absorption bands in FTIR analysis, identifying the similarity between them.

The use of pectinase in the production process resulted in a fermentation efficiency of approximately $70 \%$, but the presence of methanol was found to be above the limits of the legislation, which makes the distillate produced using this enzyme unfit for consumption. Without pectinase addition, there was no significant methanol formation, but the yield fell to about $50 \%$, due to the incomplete degradation of the sweet potatoes. Even with a lower yield, this is not an economic problem for production, since the profit margin in the production of the beverage is higher than, for example, in the production of fuel ethanol.

Funding: This research was funded by National Council for Scientific and Technological Development (CNPq) and the Federal University of Rio Grande do Sul (UFRGS).

Conflicts of Interest: The authors declare no conflict of interest.

\section{REFERENCES}

1. Valeriano IH, Marques GLL, Freitas SP, Couri S, Penha EM, Gonçalves M. Cassava Pulp Enzymatic Hydrolysate as a Promising Feedstock for Ethanol Production. Brazilian Arch Biol Technol. 2018; 61:1-10.

2. Empresa Brasileira de Pesquisa Agropecuária (EMBRAPA): Sistemas de produção [Production Systems] [Internet]. Brazil: Embrapa Hortaliças; 2008 Jun [cited 2017 May 11]. Available from: https://sistemasdeproducao.cnptia.embrapa.br/FontesHTML/Batata-doce/Batatadoce_Ipomoea_batatas/composicao_uso.html.

3. Empresa Brasileira de Pesquisa Agropecuária (EMBRAPA): Batata-doce BRS Cuia [BRS Cuia Sweet Potato] [Internet]. Brazil: Embrapa Clima Temperado; 2011 [cited 2017 May 11]. Available from: https://www.embrapa.br/clima-temperado/busca-de-solucoes-tecnologicas/-/produto-servico/1003/batata-docebrs-cuia.

4. FAO. Statistical Website [Internet]. FAOSTAT; 2012 [cited 2016 Apr 18] Available from: http://www.fao.org/faostat/en/\#data.

5. Instituto Brasileiro de Geografia e Estatística (IBGE). Produção Agrícola Municipal - Culturas Temporárias e Permanentes [Municipal Agricultural Production - Temporary and Permanent Crops]. Vol. 41. Rio de Janeiro (Brazil): IBGE; 2014. p.1-100.

6. Filho WGV. Indústria de Bebidas - Inovação, Gestão e Produção [Beverage Industry - Innovation, Management and Production]. 1st ed. São Paulo (Brazil): Blucher; 2011.

7. Pellegrini C. The Shochu Handbook - An Introduction To Japan's Indigenous Distilled Drink. 1st ed. Telemachus Press, LLC; 2014.

8. National Tax Agency. The 139th National Tax Agency Annual Statistics Report. Japan; 2013.

9. Yoshizaki Y, Takamine K, Shimada S, Uchihori K, Okutsu K, Tamaki H, et al. The Formation of $\beta$-Damascenone in Sweet Potato Shochu. J Inst Brew. 2011; 117(2):217-223.

10. Ministério da Agricultura Pecuária e Abastecimento (MAPA). Instrução Normativa No 15, de 31 de Março de 2011 [Normative Instruction No 15 of March 31, 2011]. Brazil; 2011.

11. Genisheva Z, Teixeira JA, Oliveira JM. Immobilized cell systems for batch and continuous winemaking. Trends Food Sci Technol. 2014; 40(1):33-47.

12. Liu Z, Zhang G, Sun Y. Mutagenizing brewing yeast strain for improving fermentation property of beer. J Biosci Bioeng. 2008; 106(1):33-38.

13. Bogdan P, Kordialik-Bogacka E. Alternatives to malt in brewing. Trends Food Sci Technol. 2017; 65:1-9.

14. Kerpes R, Fischer $S$, Becker $T$. The production of gluten-free beer: Degradation of hordeins during malting and brewing and the application of modern process technology focusing on endogenous malt peptidases. Trends Food Sci Technol. 2017; 67:129-138.

15. Jiao A, Xu X, Jin Z. Research progress on the brewing techniques of new-type rice wine. Food Chem. 2017; 215:508-515.

16. Wei XL, Liu SP, Yu JS, Yu YJ, Zhu SH, Zhou ZL, et al. Innovation Chinese rice wine brewing technology by biacidification to exclude rice soaking process. J Biosci Bioeng. 2017; 123(4):460-5. 
17. Schweinberger CM. Inovação e Otimização no Processo de Produção de Etanol a Partir de Batata-doce [Innovation and Optimization in the Sweet Potato Ethanol Production Process] [thesis]. Porto Alegre (Brazil): Universidade Federal do Rio Grande do Sul; 2016.

18. Masiero SS, Peretti A, Trierweiler LF, Trierweiler JO. Simultaneous cold hydrolysis and fermentation of fresh sweet potato. Biomass and Bioenergy. 2014; 70:174-83.

19. Schweinberger CM, Putti TR, Susin GB, Trierweiler JO, Trierweiler LF. Ethanol production from sweet potato: effect of ripening, comparison of two heating methods, and cost analysis. Can J Chem Eng. 2016; 94:716-24.

20. Weber CT, Trierweiler LF, Casagrande T, Trierweiler JO. Economic evaluation of sweet potato distilled beverage produced by alternative route. Int J Dev Sustain. 2018; 7(10):2514-27.

21. Zenebon O, Pascuet NS, Tiglea P. Métodos físico-químicos para análise de alimentos [Physicochemical methods for food analysis]. 4th ed. São Paulo (Brazil): Instituto Adolfo Lutz; 2008.

22. Schweinberger CM, Trierweiler JO, Trierweiler LF. Preheating Followed by Simultaneous Viscosity Reduction, Hydrolysis, and Fermentation: Simplifying the Process of Ethanol Production from Sweet Potato. BioEnergy Res. 2019; 12(1):94-102.

23. Schweinberger CM, Trierweiler JO, Trierweiler LF. A Simple Equation for Total Reducing Sugars (TRS) Estimation on Sweet Potato and Ethanol Yield Potential. Brazilian J Chem Eng. 2019; 36(1):33-41.

24. Oliveira CR, Garíglio H, Ribeiro M, Alvarenga M, Maia FX. Cachaça de alambique Manual de boas práticas ambientais e de produção [Still Cachaça Manual of Good Environmental and Production Practices]. Brazil: Convênio de Cooperação Técnica SEAPA/SEMAD/AMPAQ/FEAM/IMA; 2005.

25. Filho WGV. Bebidas Alcoólicas - Ciência e Tecnologia [Alcoholic Beverages - Science and Technology]. 2nd ed. São Paulo (Brazil): Blucher; 2016.

26. Ball S, Bullock S, Lloyd L, Mapp K, Ewen A. Analysis of carbohydrates, alcohols, and organic acids by ion-exchange chromatography - Agilent Hi-Plex Columns Applications Compendium. USA: Agilent Technologies; 2011.

27. Vilela FJ, Cardoso M, Masson J, Anjos JP. Determinação das composições físico-químicas de cachaças do sul de minas gerais e de suas misturas [Determination of physicochemical compositions of cachaça from southern Minas Gerais and their mixtures]. Ciência e Agrotec. 2007; 31(4):1089-1094.

28. Buglass AJ. Handbook of Alcoholic Beverages: Technical, Analytical and Nutritional Aspects. UK: Wiley; 2010.

29. Ferreira MMC. Quimiometria: Conceitos, Método e Aplicações [Chemometrics: Concepts, Method and Applications]. 1st ed. São Paulo (Brazil): UNICAMP; 2015.

30. Souza AM, Poppi RJ. Experimento didático de quimiometria para análise exploratória de óleos vegetais comestíveis por espectroscopia no infravermelho médio e análise de componentes principais: um tutorial, parte I [Chemometric didactic experiment for exploratory analysis of edible vegetable oils by medium infrared spectroscopy and principal component analysis: a tutorial, part I]. Quim Nova. 2012; 35(1):223-9.

31. Sádecká J, Tóthová J. Fluorescence Spectroscopy and Chemometrics in the Food Classification - a Review. Czech J Food Sci. 2007; 25(4):159-73.

32. Swain MR, Mishra J, Thatoi H. Bioethanol Production from Sweet Potato (Ipomoea batatas L.) Flour using CoCulture of Trichoderma sp. and Saccharomyces cerevisiae in Solid-State Fermentation. Brazilian Arch Biol Technol. 2013; 56(2):171-9.

33. Santiago WD, Cardoso M, Santiago J, Teixeira ML, Barbosa RB, Zacaroni LM, et al. Physicochemical profile and determination of volatile compounds in cachaça stored in new oak (Quercus sp.), amburana (Amburana cearensis), jatoba (Hymenaeae carbouril), balsam (Myroxylon peruiferum) and peroba (Paratecoma peroba) casks by SPMEGC-MS. J Inst Brew. 2016; 122(4):624-34.

34. Blinder $F$, Voges $E$, Lauge $P$. The problem of methanol concentration admissible in distilled fruit spirits. Food Addit Contam. 1988; 5(3):343-51.

35. Badolato ESG, Duran MC. Risco de intoxicação por metanol pela ingestão de bebidas alcoólicas [Risk of methanol poisoning by alcoholic beverage consumption]. Rev Psiquiatr Clínica. 2000; 27(2):1-4.

36. Yuan HW, Tan L, Luo S, Chen H, Yi X, Sun ZY, et al. Development of a process for producing ethyl caproate- and ethyl lactate-rich rice shochu. J Inst Brew. 2015; 121(3):432-9.

37. Kolbe H, Beckmann S. Development, growth and chemical composition of the potato crop (Solanum tuberosum L.) II Tuber and whole plant. Potato Res. 1997; 40:135-53.

38. Leonel M, Cereda MP. Avaliação da celulase e pectinase como enzimas complementares, no processo de hidrólise-sacarificação do farelo de mandioca para produção de etanol [Evaluation of cellulase and pectinase as complementary enzymes in cassava meal hydrolysis-saccharification process for ethanol production]. Ciência e Tecnol Aliment. 1999; 19(1):113-7. 
39. Zhang L, Zhao H, Gan M, Jin Y, Gao X, Chen Q, et al. Application of simultaneous saccharification and fermentation (SSF) from viscosity reducing of raw sweet potato for bioethanol production at laboratory, pilot and industrial scales. Bioresour Technol. 2011; 102(6):4573-9.

40. Sen I, Ozturk B, Tokatli F, Ozen B. Combination of visible and mid-infrared spectra for the prediction of chemical parameters of wines. Talanta. 2016; 161:130-7.

41. Nordon A, Mills A, Burn RT, Cusick FM, Littlejohn D. Comparison of non-invasive NIR and Raman spectrometries for determination of alcohol content of spirits. Anal Chim Acta. 2005; 548:148-58.

(C) (7) (5) 2020 by the authors. Submitted for possible open access publication under the terms and cc) $\mathrm{EY}$ NC conditions of the Creative Commons Attribution (CC BY NC) license (https://creativecommons.org/licenses/by-nc/4.0/). 